\title{
Neuropsychomotor development and auditory skills in preschool children
}

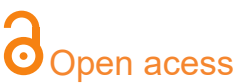

${ }^{1}$ Departamento de Fonoaudiologia da Universidade Federal de Sergipe (UFS)- Lagarto (SE), Brasil

\section{Corresponding author:} raphaelabgg@gmail.com

Manuscript received: November 2017 Manuscript accepted: December 2017 Version of record online: March 2018

\begin{abstract}
Raphaela Barroso Guedes-Granzotti ${ }^{1}$, Layna Santos Siqueira ${ }^{1}$, Carla Patrícia Hernandez Alves Ribeiro Cesar ${ }^{1}$, Kelly Silva ${ }^{1}$, Danielle Ramos Domenis ${ }^{1}$, Rodrigo Dornelas ${ }^{1}$, Aline Cabral de Oliveira Barreto ${ }^{1}$
\end{abstract}

\begin{abstract}
Introduction: Neuropsychomotor development and auditory abilities, influenced by biological and environmental factors, are directly related to school performance. In this way, a screening test in school environment allows the prior identification of change in development, reducing the losses in child life.
\end{abstract}

Objective: To characterize the relationship between neuropsychomotor development and auditory processing skills in preschool children.

Methods: 108 preschool children from three public institutions with ages between four years and one month to five years and eleven months, of both sexes were screened. It was performed the screening of Central Auditory Processing (CAP) through the simplified evaluation of auditory processing and the neurodevelopment using the Developmental Screening Test II Denver. The data were analyzed by chi-square tests and bivariate correlation with Pearson coefficient, adopting a significance level of $5 \%$ and alpha of 0.1 .

Results: The screening of the CAP, $100 \%$ of the subjects showed normal responses in the test detection, $81.5 \%$ in sound localization, $49 \%$ in the test of non-verbal sequential memory and $58.3 \%$ in the test of verbal sequential memory. In the neuropsychomotor development screening, the frequency of appropriate responses to the chronological age was significant in all areas, being $86.1 \%$ (93) in personal social area, $92.5 \%(100)$ in the adaptive fine motor, $87 \%(94)$ in language and $92.5 \%$ (100) in gross motor. It was found a significant relationship only between the language alterations and proofs of sequential memory $(p<0.05)$.

Conclusion: It was found that the group studied was relationship between the language alterations and alterations in the temporal ordering skills of the central auditory processing.

Keywords: school health, triage, auditory perception, child development, speech language and hearing sciences. 


\section{INTRODUCTION}

Children's neuropshycomotor development is a process that begins in the uterus then progresses, stage by stage, and at each stage the child acquires new skills. Although it has a fixed sequence, the rhythm of development varies from child to child, allowing the establishment of normality limits and minimum and maximum ages in the development milestones ${ }^{1,2}$.

It involves aspects ranging from neurological maturation and physical growth to the aquisition of skills related to behavior and to the cognitive, affective and social spheres of the child; as the result of the interaction between genetic, biological and environmental factors. The first years of life are marked by important motor, physical, mental and social formations and it is the period which the child has a special sensitivity to the stimuli coming from the environment, by virtue of their sensorial perceptions ${ }^{3}$.

Among the possibilities of perception of stimuli hearing, more specifically, auditory processing comes to the forefront as it has an important role to play in determining how the peripheral and central auditory system receives, analyzes and organizes this information. It consists of a series of processes involved in auditory abilities, including detection, sensation, discrimination, location, recognition, comprehension, attention and memory for sounds $\mathrm{s}^{4,5}$.

The development of these abilities depends on processes involving complex nerve pathways, which can be affected by environmental, social and pathological factors leading to a functional hearing disorder in which the child detects sounds normally but has difficulties

\section{METHODS}

One hundred and eight (108) preschool children participated in this cross-sectional, observational, analytical study. They were enrolled in three public institutions of early childhood education, with ages between four years and one month old and five years and eleven months old. Children with normal mobility of the tympanic-ossicular system and presence of acoustic reflexes were included in the study. Children with alterations in the external or middle ear, such as obstructions in the external auditory canal and otitis, or with reports (by a teacher or family members) of intellectual or hearing disability, were excluded from the study. During screening, temporary exclusion factors that could affect the performance of the child were considered, such as sleepiness, fatigue, illness, fever, fear or the refuse to participate in the study, with the screening being interrupted and resumed at another time, without loss to its validity. The research was approved by the Research Ethics Committee of the University where it was held and those responsible for the participants signed the Free and Informed Consent Term.

Within the school environment, in a quiet room without distractions, the following procedures were performed: interpreting them. Children who have this difficulty may present changes in several aspects of neuropsychomotor development such as speech and language development, speech understanding in a noisy environment, dysgraphia, inappropriate social behavior (agitation and distraction), poor school performance and inattentiveness to sound ${ }^{6}$.

The research ${ }^{7.8}$ shows that gaps in the development of preschoolers may compromise school performance and opportunities in the future. Therefore, greater vigilance should be given in the first five years through early interventions to mitigate such gaps and prevent developmental changes from going unnoticed, only becoming evident when the child demonstrates difficulties at school ${ }^{9}$.

One of the possibilities for the early identification of development changes is through screening, aiming to evaluate a large number of people in order to offer detection and intervention as early as possible. With the need for extensive reach, a procedure should be adopted that is quick, easy to apply, yet valid and reliable ${ }^{10}$.

The relationship between alterations in central auditory processing and learning difficulties in the school phase has been widely discussed in literature ${ }^{11-13}$. However, there is little discussion about the relationship between neuropsychomotor development and auditory abilities in the preschool phase, which would allow the detection and early intervention regarding changes in these skills before the beginning of the literacy process.

Given the above, this study aimed to characterize the relationship between neuropsychomotor development and auditory processing skills in preschool children.

\section{a) Screening of the auditory function:}

Initially, a meatoscopy was performed with the purpose of observing external/middle ear alterations that could hinder the hearing test. Then, the immittanciometry (tympanometry and acoustic reflex research) was performed using the MT10/ Interacoustics portable immitometer with a $226 \mathrm{~Hz}$ probe tone. The acoustic reflex was ipsilateral for the frequencies of $500,1000,2000$ and $4000 \mathrm{~Hz}$ regarding the fixed intensity of $100 \mathrm{dBNPS}$. The child PASSED, at this stage of the screening, when he presented a tympanometry curve type $\mathrm{A}$ and presence of acoustic reflex, in all the frequencies. After the selection of the subjects who underwent immitanciometry evaluation, they were submitted for simplified screening of central auditory processing $(\mathrm{ASPA})^{14}$ and neuropsychomotor development (Denver II $)^{15}$.

\section{b) Simplified auditory processing Screening} (ASPA): Sound detection and sound localization (SL) tests were performed using a rattle. The children were instructed to remain with their eyes closed during the presentation of the stimulus and, at the end of the auditory stimulation they had to 
point in the direction from which the sound came. The sound stimulus was percussed in the following positions: above the head, in front of it, behind it and in its right and left sides.

For the non-verbal sequential memory test (MSNV), musical instruments such as the rattle, the agogô (two cone shaped bells), a bell, and a blackblack (similar to castanets) were used. Before the screening itself, the evaluator presented the sounds of each instrument. The child, then, could identify them, and the evaluator performed a demonstration of the test, with the child positioned facing the instruments and pointing out the order presented. Then, three different sequences were offered, using three musical instruments in each, with the child not being able to see. Therefore, it was possible to point the correct sequence.

The "pa", "ta", "ca" syllables were used for the verbal sequential memory (MSV) test, and, initially, the child was asked to produce each syllable separately to verify the possibility of phono-articulatory production. The evaluator, then, pronounced the syllables in three different sequences, without a visual clue, and the child was asked to repeat the sequence of syllables heard.

The responses were analyzed separately, regarding their occurrence, based on pre-established normality criteria for the age group studied ${ }^{11}$. In the SL test, the child had to answer correctly four of the five directions presented, from the age of three. The error can occur in the directions above the head, in front of it, or behind it. In the MSNV test, children aged between four to six years old should answer correctly two sequences of three sounds in three attempts. From the age of six, they should answer correctly two sequences of four sounds in three attempts. In the MSV test, the child older than three years old should get at least two of the three threesyllable sequences presented correctly. At six, they are able to repeat sequences of four syllables.

The cochlear-eyelid reflex (CPR) was investigated with the musical instrument called agogô (109 dBA) and the responses were analyzed

\section{RESULTS}

Of the 108 children, $54.6 \%$ (59) were males with a mean age of $4.4( \pm 0.97)$ years old and $45.4 \%$ (49) were females, with a mean age of $3.9( \pm 1.06)$ years, with no statistically significant differences between the groups.

In the simplified screening of auditory processing (ASPA), 100\% (108) presented normal responses in the detection test, $81.5 \%$ (88) in the sound localization, $49 \%$ (53) in the nonverbal sequential memory test (MSNV), and $58.3 \%(63)$ in the verbal sequential memory test (MSV). In the MSNV ( $>0.05)$ and MSV $(p>0.05)$ tests, no significant differences were found between altered and normal responses.

In the studied population, $30.5 \%$ (33) presented a risk for development delay in at least one of the evaluated areas. The frequency of appropriate responses regarding the presence or absence of the reflex during the percussion of the instrument.

\section{c) Screening of the neuropsychomotor development:}

The Denver Development Screening Test II ${ }^{15}$ was used. It is comprised of 125 items that evaluate four areas of child development: a) Personal-Social: aspects of the child's sociability inside and outside the family environment; b) Adaptive Fine Motor: visual-manual coordination, manipulation of small objects; c) Language: sound emission, ability to recognize, understand and use language and; d) Gross motor: body motor control, sitting, walking, jumping and other movements performed by the broad musculature.

Throughout the screening, the test was interrupted if the child felt tired or had to participate in another activity at school, being resumed at another time without harm to the validity of the results. The results of each of the evaluated areas were considered as normal, risky or non-testable according to the interpretation of the test for each evaluated item, using the following criterion: normal, when there were no delays or at most one "caution"; risk of delay, when there were two or more "caution" or one or more delays; Non-testable when the child refused to perform one or more items.

In the statistical analysis, the data were tabulated and processed in SPSS Statistics data publisher software, version 21.0. For the description of the data, it was used the tabular and graphical presentation of the means, standard deviations and confidence intervals. The bivariate correlation test was applied with the Pearson coefficient to analyze the correlation of changes between the development areas evaluated, language, gross motor, adaptive fine motor and personal social; and to correlate to the changes in each of the development areas evaluated with the age variable. The chi-square test was used to compare the changes in each of the areas between the genders. The values were considered significant for $\mathrm{p} \leq 0.05$ and the accepted alpha value of 0.1 .

to chronological age in the Denver II Test was significant in all areas, being $86.11 \%$ (93) in the personal social area, $92.5 \%$ (100) in the adaptive fine motor, $87 \%(94)$ in language and $92.5 \%$ (100) in the gross motor. Comparing the performance between the genders, no significant differences were observed in the personal social area $(p$ $=0.69)$, gross motor $(\mathrm{p}=0.71)$ and language $(\mathrm{p}=0.09)$. However, in the adaptive fine motor, it was found a better performance among the female gender $(\mathrm{p}<0.05)$.

Using the bivariate correlation test between the results found in the neuropsychomotor development screening (Table 1) and the abilities assessed in the ASPA, a statistically significant relationship was found only between the language changes and the MSV $(p<0,01)$ and MSNV $(\mathrm{p}<0.05)$ tests (Table 1$)$. 
Table 1: Co-occurrence of the Denver II and ASPA results $(n=108)$

\begin{tabular}{ccccccccc}
\hline & \multicolumn{4}{c}{ LGG } & Penver II Normal & \multicolumn{5}{c}{ Denver II Risk } \\
& & MFA & MG & LGG & PS & MFA & MG \\
\hline ASPA Normal & 53 & 47 & 53 & 53 & 3 & 9 & 3 & 3 \\
MSNV & 61 & 57 & 60 & 62 & 3 & 7 & 4 & 2 \\
MSV & 94 & 93 & 100 & 100 & 14 & 15 & 8 & 8 \\
D & 77 & 77 & 81 & 80 & 11 & 11 & 7 & 8 \\
L & & & & & & & & \\
ASPA Risk & 41 & 46 & 47 & 47 & $11^{*}$ & 6 & 5 & 5 \\
MSNV & 33 & 36 & 39 & 38 & $11^{* *}$ & 8 & 5 & 6 \\
MSV & 0 & 0 & 0 & 0 & 0 & 0 & 0 & 0 \\
D & 17 & 16 & 19 & 20 & 3 & 4 & 1 & 0 \\
L & & & & & & & & \\
\end{tabular}

LGG = Language; PS = personal-social; MFA = adaptive fine motor; MG = gross motor; $\mathrm{D}$ = detection; $\mathrm{L}$ = sound localization; MSNV = non-verbal sequential memory; MSV = verbal sequential memory

${ }^{*} p<0,05{ }^{* *} p<0,01$ according to Pearson's test

\section{DISCUSSION}

The analysis of the results of the relationship between neuropsychomotor development and auditory processing abilities showed a positive association in the language area with the nonverbal sequential memory (MSNV) and verbal sequential memory (MSV) abilities, evidencing the greater probability that children with changes in auditory processing have also a risk of language development changing.

Considering the organization of language in subsystems and that, among them, the development of the phonological system and the semantic system are the ones that receive the most influence from the hearing abilities, we found studies that relate the alterations of the auditory processing to the presence of phonological ${ }^{16-19}$ and of vocabulary ${ }^{18}$ alterations, corroborating the findings of this study.

This study is relevant, however, because the findings were evidenced through screenings that can be applied to children within the school environment. The Denver II Development Screening Test ${ }^{15}$ is a widely used test, because it has good validity and reliability, it is easy and quick to apply, with low cost and allows easy training, being used in both research and clinical practice, as well as the Simplified Auditory Processing Trial (ASPA). This test is also widely used in literature because it is easy to apply and indicates a possible alteration of the auditory function ${ }^{20,21}$. It should be noted that, in both cases, since they are tests with altered responses, a specific evaluation is required to confirm or refute the "problems" detected.

Hearing experiences play an important role in the individual's ability to communicate, understand, socialize and especially in learning processes. In order to learn specifically about reading and writing, the student must be able to associate a phonemic auditory component with a graphic visual component, perceiving and understanding the graphophonic correspondence. Studies identify the development of oral language, phonological awareness, working memory and auditory abilities ${ }^{16,22,23}$ as the predictors of the literacy process.
All these predictors need to be developed in the preschool period, since the experiences lived in these years are related to the cognitive and neuropsychomotor development and dependent on the quality of the stimuli received, which may come from both the family and the school environment ${ }^{24}$. Justifying, thus, the importance of early detection of changes in this period.

The school environment, more specifically kindergartens or early childhood education institutions, began to play a major social role since the 1970s, regarding the needs and rights of working women, aiming to eliminate discrimination against women as mothers and their consequent exclusion or marginalization in the labor market. Since 1996, with the promulgation of the Lei de Diretrizes e Bases da Educação Nacional - National Education Bases and Guidelines- (LDB), the children's education began to be considered as the first stage of basic education. Therefore, it rejects an assistentialist character, in order to assume an educational role, aiming at the integral development of the child up to 6 years old, regarding physical, psychological, intellectual and social aspects. Thus, complementing the roles played by the family and the community ${ }^{25}$.

Under this new perspective, studies regarding the influence of the school environment have observed that early childhood institutions, with adequate equipment, good quality of care and adequate pedagogical methodology have a positive influence on child development. Early identification of changes in this development ${ }^{26,27}$ considering that the early recognition of disorders, followed by appropriate interventions, can reduce the disadvantages in the lives of the affected children, enabling their school and social development-, as well as providing a better quality of life, were also highlighted ${ }^{28}$.

However, it is important to highlight the high prevalence of children at risk for neuropsychomotor development delays found in this study, which corroborates with Brazilian studies using a similar research procedure ${ }^{6,29-35}$. Biscegli et al. ${ }^{29}$, Souza et al. ${ }^{30}$, Brito et al. ${ }^{6}$, Torquato et al..$^{31}$ 
and Amaro et al..$^{35}$ found a $37 \%, 30.2 \%, 46.3 \%, 31.6 \%$ and $37.35 \%$, respectively, prevalence of neuropsychomotor development delay level, using the Denver II Screening Test in preschoolers of public institutions.

Likewise, it was found a high incidence of alterations in the simplified evaluation of auditory processing, and this prevalence of failures is in line with studies that used the same instrument in school and preschool children ${ }^{16,18,28,33}$. Also in line is the observation of a greater difficulty in verbal sequential memory (MSV) and non-verbal sequential memory (MSNV), which evaluate the auditory ability of simple temporal ordering, than in the evidence of location and discrimination of the sound source ${ }^{11,17,28,33}$.

Although this study did not aim to analyze the quality of the institutions, based on the observations of the researchers during the screening and the data found in other studies ${ }^{29,35,36}$, it can be said that, in general, day care centers and public pre-schools in Brazil work poorly. It happens due to the lack of resources, lack of infrastructure, unprepared employees and the implementation of routines predominantly focused on basic nutrition and hygiene. This fact may have influenced the high prevalence of changes.
Regarding the greater number of male children, since it was a small difference, it did not put the sample out of balance and made it possible to compare performance in each of the areas of neuropsychomotor development, with no significant difference between the sexes in the personalsocial, language and gross motor areas, as shown in other studies $^{31,34,35}$. However, diverging from these observations, there was a lower performance in males in the adaptive fine motor area, a fact that can be justified by the preferential play between the two groups, since boys prefer activities that require less maturation of fine motor activities, such as playing soccer, cycling and simulation of fights ${ }^{9}$.

The positive association between the responses obtained in the screenings among the neuropsychomotor language development area and the MSV and MSNV tests are justified by the fact that time sequencing is related to short-term auditory memory. A necessary ability to recognize, identify and order acoustic stimuli, according to their order of presentation, over a certain period. This skill is also necessary for language development, since speech and language comprehension depend on the ability to work with a sound sequence ${ }^{6,36}$.

the school environment. Despite that, future research is needed to minimize some of the limitations detected in this study, such as sample size and number of institutions included, as well as the need to use instruments that can evaluate both the school and family environment and its relation to child development. In addition, it is important to note that evaluation instruments are used to confirm the variations found in the tests, making the results more consistent and allowing a generalization of these findings.

\section{REFERENCES}

1. Bornstein $\mathrm{MH}$, Hendricks $\mathrm{C}$. Screening for developmental disabilities in developing countries. Soc Sci Med. 2013;97:307-15. DOI: http://dx.doi.org/10.1016/j.socscimed.2012.09.049

2. Miranda LP, Resegue R, Figueiras ACM. Children and adolescents with developmental disabilities in the pediatric outpatient clinic. J Pediatr (Rio J). 2003;79 (Suppl 1):S33-42. DOI: http://dx.doi.org/10.1590/S0021-75572003000700005

3. Ré AHN. Crescimento, maturação e desenvolvimento na infância e adolescência: Implicações para o esporte. Motri. 2011; 7(3):55-67.

4. Rosselli M, Matute E, Ardila A. Predctores neuropsicológicos de la lectura en espanhol. Rev Neurol. 2006;42:202-10.

5. Toscano RDGP, Anastasio ART. Habilidades auditivas e medidas de imitância acústica em crianças de 4 a 6 anos de idade. Rev CEFAC. 2012;14(4):650-8. DOI: http://dx.doi.org/10.1590/S1516-18462011005000080

6. Fridlin SL, Pereira LD, Perez AP. Relação entre dados coletados na anamnese e distúrbio do processamento auditivo. Rev CEFAC. 2014;16(2):405-12. DOI: http://dx.doi.org/10.1590/1982-0216201416312

7. Ferguson KT, Cassells RC, MacAllister JW, Evans GW. The physical environment and child development: an international review. Int J Psychol. 2013;48(4):437-68. DOI: http://dx.doi.org/10.1080/00207594.2013.804190

8. Barnett WS, Masse LN. Comparative benefit-cost analysis of the abecedarian program and policy implications. Econ Educ Rev. 2007;26(1):113-25.

DOI: http://dx.doi.org/10.1016/j.econedurev.2005.10.007 
9. Brito CML, Vieira GO, Costa MCO, Oliveira NF. Desenvolvimento neuropsicomotor: o teste de Denver na triagem dos atrasos cognitivos e neuromotores de pré-escolares. Cad Saúde Pública. 2011;27(7):140314. DOI: http://dx.doi.org/10.1590/S0102-311X2011000700015

10. Sigolo ARL, Aiello ALR. Análise de instrumentos para triagem do desenvolvimento infantil. Paideia. 2011;21(48):51-60. DOI: http://dx.doi.org/10.1590/S0103-863X2011000100007

11. Pelitero T M, Manfredi AKS, Schneck APC. Avaliação das habilidades auditivas em crianças com alterações de aprendizagem. Rev CEFAC. 2010;12(4):662-70. DOI: http://dx.doi.org/10.1590/S1516-18462010005000062

12. Engelmann L, Ferreira MIDC. Avaliação do processamento auditivo em crianças com dificuldades de aprendizagem. Rev Soc Bras Fonoaudiol. 2009;14(1):69-74. DOI: http://dx.doi.org/10.1590/S1516-80342009000100012

13. Capovilla FC. Triagem de processamento auditivo central em crianças de 6 a 11 anos. Rev Bras Cresc Desenvol Hum. 2002; 12(2):29-41. DOI: http://dx.doi.org/10.7322/jhgd.39692

14. Pereira LD. Processamento Auditivo: Abordagem passo a passo. In: Pereira LD, Schochat E. Processamento auditivo central: manual de avaliação. São Paulo: Lovise, 1997.

15. Frankenburg WK, Dodds J, Archer P, Shapiro H, Bresnick B. Denver II techinal manual. Denver: Denver Developmental Materials Inc.; 1990.

16. Souza VC, Dourado JS, Lemos SMA. Fonologia, processamento auditivo e educação infantil: influências ambientais em crianças de 4 anos a 5 anos e 11 meses. Rev CEFAC. 2015;17:512-20. DOI: http://dx.doi.org/10.1590/1982-0216201516513

17. Attoni TM, Quintas VG, Mota HB. Avaliação do processamento auditivo e da discriminação fonêmica em crianças com desenvolvimento fonológico normal e desviante. Braz J Otorhinolaryngol. 2010;76(6):7628. DOI: http://dx.doi.org/10.1590/S1808-86942010000600015

18. Souza MA, Passaglio NJS, Souza VC, Scopel RR, Lemos SMA. Ordenação temporal simples e localização sonora: associação com fatores ambientais e desenvolvimento de linguagem. Audiol Commun Res. 2015;20(1):24-31. DOI: http://dx.doi.org/10.1590/S2317-6431201500010000144

19. Attoni TM, Quintas VG, Mota HB. Processamento auditivo, reflexo acústico e expressão fonológica. Braz. J Otorhinolaryngol. 2010;76(6):753-61.

DOI: http://dx.doi.org/10.1590/S1808-86942010000600014

20. Silva NDSH, Lamy Filho F, Gama MEA, Lamy ZC, Pinheiro AL, Silva DN. Instrumentos de avaliação do desenvolvimento infantil de recém-nascidos prematuros. J Hum Growth Dev. 2011;21(1):85-98. DOI: http://dx.doi.org/10.7322/jhgd.19998

21. Vargas GC, Ferreira MIDC, Vidor DCGM, Machado MS. Avaliação simplificada e comportamental do processamento auditivo em escolares: estabelecendo relações. Rev CEFAC. 2014;16(4):1069-77. DOI: http://dx.doi.org/10.1590/1982-021620142413

22. Granzotti RBG, Furlan SA, Domenis DR, Fukuda MTH. Memória de trabalho fonológica e consciência fonológica em crianças com dificuldade de aprendizagem. Distúrb Comum. 2013;25(2):241-52.

23. Cardoso AMS, Silva MM, Pereira MMB. Consciência fonológica e a memória de trabalho de crianças com e sem dificuldades na alfabetização. CoDAS. 2013;25(2): 110-4. DOI: http://dx.doi.org/10.1590/S2317-17822013000200004

24. Corsi C, Santos MM, Marques LAP, Rocha NACF. Repercussões de fatores extrínsecos no desempenho motor fino de crianças frequentadoras de creches. Rev Paul Pediatr. 2016;34(4):439-46. DOI: http://dx.doi.org/10.1016/j.rppede.2016.03.007

25. Brasil. Presidência da República. Lei no 9394 de 20 de dezembro de 1996. Dispõe sobre as diretrizes e bases da educação. [cited 2016 May 9] Available from: http://www.planalto.gov.br/ccivil_03/leis/L9394.htm

26. Baltieri L, Santos DCC, Gibim NC, Souza CT, Batistela ACT, Tolocka RE. Desempenho motor de lactentes frequentadores de berçários em creches públicas. Rev Paul Pediatr. 2010;28(3):283-9. DOI: http://dx.doi.org/10.1590/S0103-05822010000300005

27. Bragança LLC, Alves CRL, Lemos SMA. Estudo do perfil comunicativo de crianças de 4 a 6 anos na educação infantil. Rev CEFAC. 2014;16(4):1273-82. DOI: http://dx.doi.org/10.1590/1982-021620140613

28. Rabelo ATV, Campos FR, Friche CP, Silva BSV, Friche AAL, Alves CRL, et al. Alterações fonoaudiológicas em crianças de escolas públicas em Belo Horizonte. Rev Paul Pediatr. 2015;33(4):4539. DOI: http://dx.doi.org/10.1016/j.rpped.2015.02.004

29. Biscegli TS, Polis LB, Santos LM, Vicentin M. Avaliação do estado nutricional e do desenvolvimento neuropsicomotor em crianças frequentadoras de creche. Rev Paul Pediatr. 2007;25(4):337-42. DOI: http://dx.doi.org/10.1590/S0103-05822007000400007 
30. Souza SC, Leone C, Takano OA, Moratelli HB. Desenvolvimento de pré-escolares na educação infantil em Cuiabá, Mato Grosso, Brasil. Cad Saúde Pública. 2008;24(8):1917-26. DOI: http://dx.doi.org/10.1590/S0102-311X2008000800020

31. Torquato JA, Paes JB, Bento MCC, Saikai GMPN, Souto JN, Lima EAM, et al. Prevalência de atraso do desenvolvimento neuropsicomotor em pré-escolares. J Hum Growth Dev. 2011;21(2):259-68. DOI: http://dx.doi.org/10.7322/jhgd.20014

32. 32. Amaro LLM, Pinto SA, Morais RLS, Tolentino JA, Felício LR, Camargos ACR, et al. Child development: comparison between children who attend or do not attend public daycare centres. J Hum Growth Dev. 2015;25(2):170-76. DOI: http://dx.doi.org/10.7322/jhgd.103002

33. Colella-Santos MF, Bragato GR, Martins PMF, Dias AB. Triagem auditiva em escolares de 5 a 10 anos. Rev CEFAC. 2009;11(4):644-53.

34. Carneiro JM, Brito APB, Santos MEA. Avaliação do desenvolvimento de crianças de uma creche através da escala de Denver II. Rev Min Enferm. 2011;15(2):174-80.

35. Guerreiro TBF, Cavalcante LIC, Costa EF, Valente MDR. Psychomotor development screening of children from kindergarten units of Belém, Pará, Brazil. J Hum Growth Dev. 2016; 26(1):181-9. DOI: http://dx.doi.org/10.7322/jhgd.119262

36. Quintas VG. A relação das habilidades do processamento auditivo com a consciência fonológica e com o desenvolvimento da fala. Rev Soc Bras Fonoaudiol. 2010;15(2):310. DOI: http://dx.doi.org/10.1590/S1516-80342010000200028

\section{Resumo}

Introdução: O desenvolvimento neuropsicomotor e das habilidades auditivas, influenciados tanto por fatores biológicos como ambientais, tem relação direta com o desempenho escolar. Dessa forma, a realização de triagens em ambiente escolar possibilita a identificação precoce de alterações nesse desenvolvimento reduzindo assim, os prejuízos na vida dessas crianças.

Objetivo: Caracterizar a relação entre o desenvolvimento neuropsicomotor e as habilidades do processamento auditivo em pré-escolares.

Método: Foram realizados em 108 pré-escolares de três instituições públicas, com idades entre quatro anos e um mês e cinco anos e 11 meses, de ambos os sexos. Foram realizadas teste de reatreio do processamento auditivo central (PAC) por meio da avaliação simplificada do processamento auditivo (ASPA) e do desenvolvimento neuropsicomotor utilizando o Teste de Triagem de Desenvolvimento Denver II. Os dados foram analisados pelos Testes Qui-quadrado e Correlação Bivariada com coeficiente Pearson, adotando-se significância de $5 \%$ e alfa de 0,1 .

Resultados: No rastreamento do PAC, $100 \%$ dos sujeitos apresentaram respostas normais na prova de detecção, $81,5 \%$ na de localização sonora, $49 \%$ na prova de memória sequencial não verbal e $58,3 \%$ na prova de memória sequencial verbal. Na triagem do desenvolvimento neuropsicomotor, a frequência de respostas adequadas à idade cronológica foi significativa em todas as áreas, sendo de $86,1 \%$ (93) na área pessoal social, 92,5\% (100) no motor fino adaptativo, 87\% (94) na linguagem e $92,5 \%$ (100) no motor grosseiro. Constatou-se relação significativa apenas entre as alterações de linguagem e as provas de memória sequencial $(p<0,05)$.

Conclusão: Houve relação entre as alterações de linguagem e as alterações nas habilidades de ordenação temporal do processamento auditivo central.

Palavras-chave: saúde escolar, triagem, percepção auditiva, desenvolvimento infantil, fonoaudiologia.

${ }^{\odot}$ The authors (2018), this article is distributed under the terms of the Creative Commons Attribution 4.0 International License (http://creativecommons.org/licenses/by/4.0/), which permits unrestricted use, distribution, and reproduction in any medium, provided you give appropriate credit to the original author(s) and the source, provide a link to the Creative Commons license, and indicate if changes were made. The Creative Commons Public Domain Dedication waiver (http://creativecommons.org/publicdomain/ zero/1.0/) applies to the data made available in this article, unless otherwise stated. 